\title{
Statyba
}

\section{PUBLIC PROCUREMENT OF CONSTRUCTION WORK: A BIMATRIX GAME MODEL}

\section{S. Mitkus}

To cite this article: S. Mitkus (2001) PUBLIC PROCUREMENT OF CONSTRUCTION WORK: A BIMATRIX GAME MODEL, Statyba, 7:4, 334-338, DOI: 10.1080/13921525.2001.10531745

To link to this article: https://doi.org/10.1080/13921525.2001.10531745

曲 Published online: 30 Jul 2012.

Submit your article to this journal $\pi$

Џ Article views: 173

Citing articles: 2 View citing articles 4 


\section{PUBLIC PROCUREMENT OF CONSTRUCTION WORK:}

\section{A BIMATRIX GAME MODEL}

\section{S. Mitkus}

\section{Vilnius Gediminas Technical University}

\section{Introduction}

In the course of public procurement of construction work the rival contractors are subject to conflict the winner takes all. Each of the bidding contractors does his best to attain his goal by offering the procuring organisation to the tender, which to the latter's opinion is the most acceptable one, thus winning the contract. Possibilities of the contractors to otherwise influence the procedure of public procurement are very limited, ie they have to comply with the "rules of game" established by the Law on Public procurement [1] and the public procurement documents of the procuring organization. In practice the only lawful way to influence the procedure of the public procurement of construction work is appealing to the Public Procurement Agency [1] against the illegal actions or decisions of the procuring institution.

The game theory is a branch of mathematics, which is just engaged in the examination of behaviour and selection of the rational rules (strategies) of behaviour for each party of the conflict situation [2]. It is obvious that application of methods of the game theory would help the contractors to prepare tenders to the public biddings for construction contracts, on the one part, and would also help the procuring organizations to better prepare public procurement documents, on the other part, thus opting for better offers.

In order to apply methods of the game theory to the public procurement of construction work one should first of all prepare the possible models of public procurement.

The papers published by J. Neumann [3] in the fourth decade of the twentieth century gave a big impetus to application of the game theory in practice. Since that time a lot of research has been conducted into the issues of applying the game theory in economy, business, law, etc $[2,4]$. E. K. Zavadskas and F. Peldschus [5] have carried out a lot of research concerning the issues of applying the game theory in construction technology and management. The works by these scientists examine widely the issues of selecting rational strategies, projects and contractors. Unfortunately, not enough research has been conducted into the issues of applying the games theory in the procedure of preparing rational offers for public procurement of construction work.

This article aims at investigating the possibilities of applying models of the game theory in public procurement of construction work, and creating the bimatrix model of public procurement of construction work.

\section{The game theory models and analysis of possi- bilities to apply them in the public procurement of construction work}

Different models of the game theory may and should be applied in different conflict situations. No single classification has been formed as yet with regard to the models of the game theory. Usually, the games and their models are classified in accordance with the number of players, number of strategies, relations between the players, character of payoffs, number of moves, and the character of the information available.

In accordance with the number of players the games are divided into one-player, two-player and $n$ player games. One-player games (of the patience card game type) are not examined in the game theory. Twoplayer games are the most popular, they are examined in the best way both theoretically and practically. Threeplayer and more-player (n-player) games are the least 
investigated. Solution of these games is considerably more difficult and the more players take part in a game the more difficult is the solution of this game.

In practice, open and limited tenders may be used in public procurement of construction work [1]. In cases of open or limited tenders where less than three offers have been received the bidding is considered a failure. Therefore, a conclusion may be drawn that an $n$-player game can in the best way describe the public procurement of construction work.

As mentioned above, application of an n-player game model is very problematic due to its complexity. Simulation and solution of public procurement of construction work (determination of rational strategies) would be considerably simpler if a two-player game model were successfully applied.

A two-player game model would be applicable in the public procurement of construction work if a precondition were made that the first player is a contractor for whom a rational strategy is to be selected, and the other player represents all the remaining contractors taking part in the public procurement procedure.

The soundness of this precondition can be explained by the fact that in case of loosing the public procurement competition there is no great difference for the contractor which place he has taken (eg the second one or seventh). Therefore, in case of public procurement the essentially important are not offers (strategies) of all the other players but the offer (strategy) of only one contractor who offered the lowest price (other best conditions) of work.

It may be also presumed that the lowest price offered by the second player (ie by all the remaining contractors taking part in the public procurement procedure) will be equal to the market price. Economists have proved [6], that in case of a perfect competition the market price objectively stabilizes in accordance with the supply and demand ratio on the market (Fig 1), and the model of the construction market in Lithuania is close to the model of a perfect competition (there are many sellers - contractors while the goods offered by competitors are similar). Since, under the abovementioned presumption, the market price stabilizes due to objective reasons (ie supply and demand on the market) we may, with certain exceptions, consider this game model a game against the nature model [4].

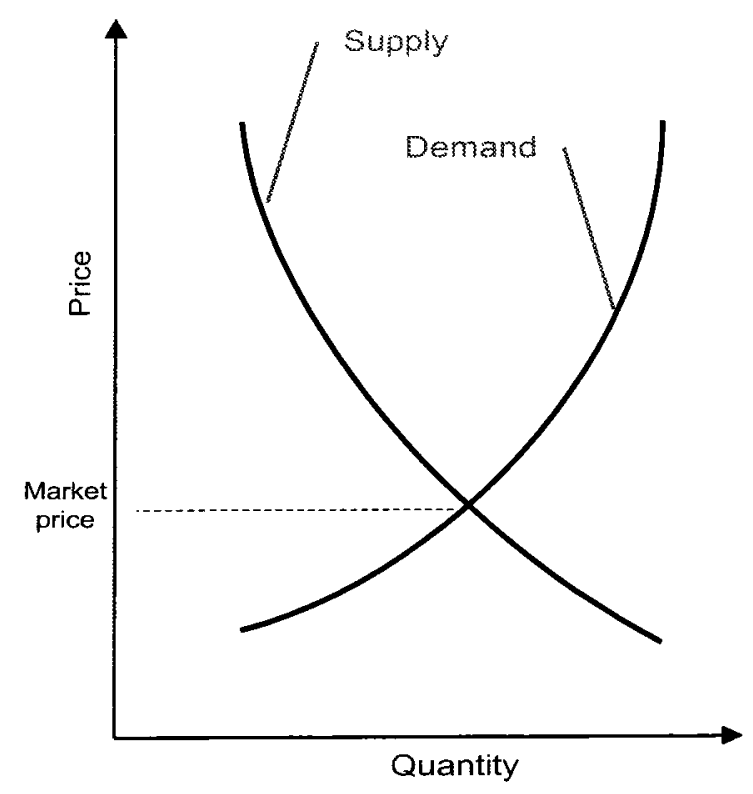

Fig 1. Supply and demand curve, market price in case of a perfect competition.

In accordance with the number of possible strategies the game models are divided into finite and infinite ones. Players of finite games have a finite number of strategies. A game is called infinite if at least one player has an infinite number of strategies.

In case of public procurement of construction work each contractor has practically an infinite number of strategies because a contractor can practically offer any price of construction work (The Law on Public Procurement sets neither the upper not lower limits of an offer price). However, in practice, contractors offer prices within a certain "reasonable" price range, ie: a normal contractor will never offer a price, which is either less than the costs of construction work or considerably higher than the market price of the procured construction work. If we take from this price range a sufficiently large number of prices, then we obtain a sufficiently precise finite game model. Therefore, a conclusion may be drawn that finite and infinite game models are applicable in public procurement of construction work, however, upon applying a finite game model it would become considerably simpler and its quality would be reduced insignificantly.

In accordance with relations between players the game models are divided into non-coalition, cooperative and coalition ones. In non-coalition games players shall not make any agreements or coalitions. In coali- 
tion games players may agree on their actions, reach a compromise and make coalitions. In cooperative games coalitions are made prior to the game.

The Law on Public Procurement [1] and Competition laws forbid making any coalitions when submitting offers for public procurement. Therefore, only a non-coalition game model is applicable in public procurement of construction work.

In accordance with the character of a payoff the game models may be divided into zero-sum games and non-zero-sum games. The payoffs of the two-player zero-sum finite game can be described by one matrix representing payoffs of one player. Payoffs of the second player are equal to the first player's wins with a minus sign. Therefore, such games are called matrix games.

In non-zero-sum games the total sum of all players is not equal to zero. Solution of such games is more difficult. In this case, to show the payoffs of the two-player game we need two matrixes or one bimatrix, ie a matrix, whereof each element consists of two wins, ie the win of the first player and the win of the second player. Therefore, the two-player non-zero-sum games are called bimatrix games.

Only one player wins the game in public procurement of construction work. The profit earned by the player after fulfilment of the contract may be considered his payoff. Other players win nothing, but nothing do they loose (except for the costs which they suffered during the preparation of offers, but these costs are comparatively small and they can be disregarded). Therefore, a non-zero-sum game model shall be applied in the public procurement of construction work. Taking into account the above-drawn conclusions covering the possibility to consider the public procurement of construction work a two-player game, it is possible to maintain that application of a bimatrix game model in the public procurement of construction game is reasonable.

In accordance with the number of moves the games are divided into static and dynamic ones. Static games come to an end after one move by the players. In dynamic games players make more than one move.

The main move by players (contractors) made in the public procurement of construction work is submission of offers. In accordance with the Law on Public
Procurement [1] sealed offers submitted by all contractors are opened simultaneously, according to which the procuring organization determines the winning offer. Therefore, the public procurement of construction work may be considered one-move games.

However, examining the process of public procurement one may notice that during this process other conflict situations may also occur, whereto the game theory methods are applicable. First of all, the above methods include protection of the players' rights of appeal against actions and decisions of the procuring organization, thus aiming at a favourable decision made by corresponding institutions. These legal conflict situations are also subject to application of the game theory methods. Therefore, dynamic game models are also applicable in the public procurement of construction work (in a wider sense).

In accordance with the information available to players with regard to the functions of the players' payoffs the games are divided into full-information games and partial-information games. In full-information games each player knows about the functions of other players' payoffs. As mentioned above, a win in the public procurement of construction work is a profit, which the contractor expects to gain by winning a contract in the course of public procurement. Certainly, one contractor cannot know the costs of the procurement object calculated by another contractor. However, if one assumes that the costs of construction work for separate contractors is sufficiently similar then the fullinformation game model is applicable to the public procurement of construction work.

Literature gives a greater number of classifications of game models. This paper covers a wider examination of the two-player non-zero sum game, ie bimatrix game model only.

\section{Formation of the bimatrix game model}

Taking into account the conclusions made in the second section hereof let us create a two-player nonzero-sum static finite full-information game model (bimatrix game model) of the public procurement of construction work.

Since bimatrix games are finite two-player nonzero-sum games the latter may be derived from $n$-player games $[2,4,5]$. In case of an $n$-player game there are 
$n$ multitudes of non-empty players' strategies $S_{i}(i=1$, $\ldots, n)$ and $n$ real functions $A_{i}(i=1, \ldots, n)$, described in the multitude $S_{1} \times S_{2} \times \ldots S_{n}$, which is a set of functions of the players' payoff. This game is expressed as follows:

$$
\mathrm{G}=\left\{S_{1}, \ldots, S_{n} ; A_{1}, \ldots, A_{n}\right\}
$$

Such a game for two players is expressed in this way:

$$
\mathrm{G}=\left\{S_{1}, S_{2} ; A_{1}, A_{2}\right\}
$$

In this case the first player has $m$ strategies $i=$ $1,2, \ldots, m$, and the second player $-n$ strategies $j=$ $1,2, \ldots, n$. Each pair of strategies $(i, j)$ has corresponding numbers $a_{i j}$ and $b_{i j}$, which express payoffs of the first and second player, respectively. Both players select their strategies and the wins are determined in accordance with their selection.

Seeking to apply the bimatrix game model in public procurement, one should make several assumptions:

1) the contractor for whom a rational strategy is to be selected should be considered the first player;

2) all the remaining contractors should be considered the second player.

3) players have a finite number of strategies. Without a doubt, the number of prices, which the contractors may offer is infinitely large. However, for practical reasons (without prejudice to results) one should examine in this type of the game model only the finite number of strategies (offers by contractors).

Let us assume that the lowest offer price is specified as an evaluation criterion in the public procurement procedure. In this case the first player prepares $m$ strategies, ie offer prices $P_{1 i}, j=1 . . m$. A presumption is made that the second player may select $n$ strategies, ie offer prices $P_{2 j}, j=1 . . n$. In this case the bimatrix of a win is as follows:

$$
\left[\begin{array}{ccccc}
a_{11}, b_{11} & \cdots & a_{1 j}, b_{1 j} & \cdots & a_{1 n}, b_{1 n} \\
\ldots & \cdots & \cdots & \cdots & \ldots \\
a_{i 1}, b_{i 1} & \cdots & a_{i j}, b_{i j} & \cdots & a_{i n}, b_{i n} \\
\ldots & \cdots & \cdots & \cdots & \cdots \\
a_{m 1}, b_{m 1} & \cdots & a_{m j}, b_{m j} & \cdots & a_{m n}, b_{m m}
\end{array}\right]
$$

Each element of the bimatrix consists of two parts, the first of which means the payoff of the first player, and the second part represents the payoff of the second player.
Determining the payoff of the first player it should be first of all taken into consideration that the player wins only in the case where he wins the public procurement procedure, ie $P_{1 i}<P_{2 j}$. An interesting situation would arise if the two contractors offered the same prices. The Law on Public Procurement does not regulate such a case. It is presumed that in this case the procuring organization might determine the winner of the public procurement procedure by casting lots when both contractors have an equal probability to win. Therefore, it would be reasonable to consider that the payoffs of both contractors are the same and equal to a half of the total payoff. In this case the win of the first player would be equal to:

$$
\begin{array}{ll}
a_{i j}=P_{1 i}-P_{s}, & \text { when } P_{1 i}>P_{2 j}, \\
a_{i j}=0, & \text { when } P_{1 i}>P_{2 j}, \\
a_{i j}=\left(P_{1 i}-P_{s}\right) / 2, & \text { when } P_{1 i}=P_{2 j},
\end{array}
$$

where $P_{s}$ is costs of construction work.

By analogy, the payoff of the second contractor would be equal to:

$$
\begin{array}{ll}
b_{i j}=P_{2 i}-P_{s}, & \text { when } P_{1 i}>P_{2 j}, \\
b_{i j}=0, & \text { when } P_{1 i}<P_{2 j}, \\
b_{i j}=\left(P_{2 i}-P_{s}\right) / 2, & \text { when } P_{1 i}=P_{2 j},
\end{array}
$$

Let us assume, that an open bidding for construction contract has been declared, whereof evaluation criterion is the minimum offer price, and the costs of construction work amounts to 10 million Litas. It is forecasted that the multitude of strategies of the second player, ie the lowest tender prices (market prices) may be:

$$
C=\{10,1 ; 10,15 ; 10,20 ; 10,25\}
$$

The contractor (the first player) determines that he is able to offer the open bidding procedure the following multitude of prices (strategies):

$$
B=\{10,05 ; 10,1 ; 10,15 ; 10,2 ; 10,25\}
$$

The bimatrix of payoffs in such game is shown in Table 1.

Upon determining the bimatrix of the wins the selection of a rational strategy should be determined by methods of the game theory. The most important task is determining possible market prices and their probability. The disadvantages of this method may include the possibility that certain contractors due to various reasons (eg incorrect calculation of the self- 
Table 1. Bimatrix of payoffs

\begin{tabular}{|c|c|c|c|c|}
\hline \multirow{2}{*}{$\begin{array}{c}\text { Strategies (tender prices) of the } \\
\text { first player, in million Litas }\end{array}$} & \multicolumn{4}{|c|}{ Strategies (market prices) of the second player, in million Litas } \\
\cline { 2 - 5 } & 10,1 & 10,15 & 10,2 & 10,25 \\
\hline 10,05 & 0,$05 ; 0,00$ & 0,$05 ; 0,00$ & 0,$05 ; 0,00$ & 0,$05 ; 0,00$ \\
\hline 10,1 & 0,$05 ; 0,05$ & 0,$10 ; 0,00$ & 0,$10 ; 0,00$ & 0,$10 ; 0,00$ \\
\hline 10,15 & 0,$00 ; 0,10$ & 0,$075 ; 0,075$ & 0,$15 ; 0,00$ & 0,$15 ; 0,00$ \\
\hline 10,2 & 0,$00 ; 0,10$ & 0,$00 ; 0,15$ & 0,$10 ; 0,10$ & 0,$20 ; 0,00$ \\
\hline 10,25 & 0,$00 ; 0,10$ & 0,$00 ; 0,15$ & 0,$00 ; 0,20$ & 0,$125 ; 0,125$ \\
\hline
\end{tabular}

cost of construction work, etc) may also offer prices that are considerably lower or higher than the market prices.

\section{Conclusions}

1. Analysis of the procedure of public procurement of construction work shows that the game theory models are applicable in this procedure. Thanks to these models and using methods of the game theory the contractors would be able to form rational strategies of participation in the public procurement of construction work.

2. The public procurement of construction work may be described in the best way by the model of the $n$-player non-zero-sum infinite dynamic partial information game.

3. Analysis of the process of public procurement of construction work shows that the model of a twoplayer non-zero-sum static full-information game (bimatrix game model) may be also applied in the public procurement of construction work if certain assumptions are made. In this case the solution of the game (selection of rational strategies) becomes considerably simpler, and all these simplifications have little influence on the results.

4. The basic problem of application of the discussed method consists in determination of specific probabilities of market prices for construction work at a specific time.

5. The paper presents only the method of forming the model of the matrix game for the public procurement of construction work. Development of methods for selecting strategies of participation in the public procurement of construction work is the object of further research.

\section{References}

1. Law on Public Procurement // Valstybès žinios, 1999, No 56, p. $3-18$.

2. P. J. Dutta. Strategies and games: theory and practice. MIT Press, 1999. 476 p.

3. J. Neumann, $O$. Morgenstern. Theory of games and economic behaviour. Princeton University Press, 1953. 432 p.

4. R. Gibbons. Game theory for applied economists. Princeton University Press, 1992. 288 p.

5. F. Peldshcus, E. K. Zavadskas. Matrix Games in construction technology and management. Vilnius: Technika, 1997. 134 p.

6. S. Dibb, L. Simkin, W. Pride. Marketing. Concepts and strategies. Boston: Houghton Mifflin Company, 1991. $739 \mathrm{p}$.

Iteikta 20010425

\section{VIEŠIEJI STATYBOS DARBŲ PIRKIMAI: BIMATRICINIS LOŠIMU TEORIJOS MODELIS}

\section{S. Mitkus}

Santrauka

Straipsnyje nagrinèjamos galimybès lošimu teorijos metodus taikyti statybos darbụ viešiesiems pirkimams. Statybos darbų viešuosius pirkimus geriausiai apibūdina $n$ lošèju lošimo modelis su ne visa informacija. Straipsnyje irodyta, kad pritaikius tam tikrus supaprastinimus gali būti taikomas bimatricinis lošimo modelis su visa informacija. Toks modelis leidžia gerokai supaprastinti lošimų teorijos uždavinio sprendimą (racionalių strategiju parinkimą).

Straipsnyje pateikta bimatricinio statybos darbų viešuju pirkimų lošimo modelio sudarymo metodika ir tokio modelio sudarymo pavyzdys.

Lošimų teorijos metodụ taikymas parenkant racionalias strategijas taikant pateiktą modelị yra tolesniu tyrimų objektas.

Sigitas MITKUS. Doctor. Assoc Prof. Dept of construction technology and management. Vilnius Gediminas Technical University (VGTU), Saulètekio al. 11, LT-2040 Vilnius, Lithuania.

Research interests: application of decision-making and game theory in construction management, construction law. 